\title{
Global instability of currencies: reasons and perspectives according to the state-corporation hegemonic stability theory
}

\author{
DARIUSZ ELIGIUSZ STASZCZAK*
}

\begin{abstract}
RESUMO: Este artigo analisa as razões da instabilidade do sistema monetário mundial. O autor considera este problema a partir de perspectivas históricas e contemporâneas. De acordo com o ponto de vista apresentado, as notas e o dinheiro eletrônico que substituiram as moedas de ouro e prata em circulação são a razão mais importante da instabilidade. Há também consequências positivas e negativas comprovadas da instabilidade do dinheiro. As reformas do sistema monetário mundial precisam de um acordo no âmbito da hegemonia global de políticas de Estado e de corporações transnacionais.

PALAVRAS-CHAVE: Instabilidade global; moedas; taxas de câmbio; lei de Kopernik; notas; valor real e simbólico; economias nacionais, fluxos de comércio e de capitais internacionais; economia global; teoria da estabilidade hegemônica.
\end{abstract}

ABSTRACT: This paper analyses reasons of the instability of the world monetary system. The author considers this problem from historical and contemporary perspectives. According to presented point of view banknotes and electronic money which replaced gold and silver coins in popular circulation are the most important reason of the instability. There are also proven positive and negative consequences of money instability. Reforms of the world monetary system need agreement within the global collective hegemony of state-powers and transnational corporations.

KEYWORDS: Global instability, currencies, exchange rates, gold and silver money, Kopernik's law, banknotes, real and symbolic value, national economies, international trade and capital flows, global economy, state-corporation hegemonic stability theory.

JEL Classification: E42.

\footnotetext{
* Uniwersytet Przyrodniczy w Lublinie, Polska, e-mail: dariusz.staszczak@up.lublin.pl. Submetido: 4/Dezembro/2013; Aprovado: 11/Junho/2014.
} 


\section{INTRODUCTION}

A problem that a worse new money displaced a better old money was discovered by Polish economist and astronomer Mikolaj Kopernik (Nicolas Copernicus), (1473-1543) in 1522-1528. Kopernik submitted his law concerning an improvement of the coin during discussions in 1522 and wrote it as memorial in 1528. He argued that some people selected old coins [that contained more silver than new ones] and drowned them to sell the silver for higher price (Kopernik, 2001, 1926, 1528). This rule is often incorrectly identified with British merchant, financier, founder of Royal Exchange of London and queen's advisor Thomas Gresham. So called "Gresham's Law" that "bad money drives out good money" was announced in 1558, i.e., after Kopernik's Law (Law of Copernicus) and after Kopernik's death in 1543. Therefore, "Gresham's Law" is not original scientific discovery but only a copy of Kopernik's Law. However, this error with "Gresham's Law" is made by American and European economists, including the U.S. Nobel Prize Laureate Paul A. Samuelson (see Samuelson \& Nordhaus, 1985; McEachern, 1988; Rothbard, 2006).

Nowadays, cotton money (so called paper money), i.e.,banknotes (notes) that only symbolize the value are more instable. Electronic (virtual) money, e.g., payments (credit or debit) cards, money in bank accounts is also instable. This situation can be profitable or unprofitable for economies of particular countries in particular time periods. My ideas are confronted with other most important theories and ideas. I try to prove two hypothesises. First one is that a lack of gold standard, i.e., merchandise value of the money is the most important reason of the global instability of currencies. I prove that Kopernik's law and changing parities between gold and silver were enough to explain instabilities of currencies in the ancient and medieval centuries. Nowadays, there is necessary to explain instability of the world monetary system that bases on really valueless money. That situation has some positive and negative features. I would like to add my opinion to discussions in this matter that the instability is an inherent occurrence of this system. However, there is open question of bigger or smaller instability of currencies. Smaller changes of exchange rates are required because of the need to stabilize the global economy but most important decisions in this matter must be agreed within the global collective hegemony of state-powers and transnational corporations according to the state-corporation hegemonic stability theory. That theory is connected with a new paradigm of the global economy, i.e. the global political-economic spiral (see Staszczak, 2002 and 2011). Therefore, my second hypothesis is that contradictory interests inside and outside the global collective hegemony which destabilize the global system (see Staszczak, 2011), are also important reasons of the global instability of currencies.

\section{HISTORICAL CAUSES}

Since the ancient centuries money meant a defined value consisted in metal, for instance gold, silver or copper. Coins were pieces of metal with a state sign which 
guaranteed a responsible weight. The most important were gold and silver coins because of a big value. There were also problems to establish a convertible ratio of gold and silver coins because of changes in the both metals prices. Therefore, there were problems of parity between silver and gold coins in the time when price of the two metals changed. Different parities in particular countries were favorable for international speculations, e.g. in trade between ancient Macedonia and ancient Persia in IV age BC. There was parity between gold and silver amounting 1:10 in Macedonia and 1:13 in Persia. A solution was to establish one metal as a major currency. In this way, silver coins were a basic currency in Holy Roman Empire (of German Nation) in the early Middle Ages. Similarly, medieval Poland use silver coins mostly. Gold coins were rare and therefore, there were not big problems with parity of exchange. Whereas, the ancient Roman Empire and the medieval Byzantine Empire used the both silver and gold coins as major currency simultaneously. Cheap copper coins played usually a substandard role (Cywinski, 1986).

A growth of gold mining in Europe in the late Middle Ages caused also problems of ratio between gold and silver coins. Nicolas Oresme (1325-1382), French Bishop of Lisieux, economist and astronomer, explained as follows: "Ratio is the comparison or habitual relation of one thing to another, just as the proportion of gold money to silver money there ought to be a definite relation in value and price [...] this proportion ought to follow the natural relation in value of gold and silver, and a ratio should be fixed, not to be arbitrarily changed, nor justly varied except for a reasonable except for a reasonable cause and alteration arising from the material, a thing which rarely happens. Thus, if it were notorious that less gold was being found than before, it would have to be dearer as compared with silver, and would change in price and value. But if there were little or no material change the prince would not be free to make such a change in price" (Oresme, 1956, 1350s).

However, the most important problem was a lack of enough gold or silver in accordance with the needs of ruling emperors, kings or princes. Therefore, there was a characteristic phenomenon of coinage damage. New coins contained less gold or silver than old pieces (Cywinski, 1986). This practice conducted to popular use a weight against to count coins in trade. People could compare better and worse coins. Another solution was a repressive replace of old better coins for new worse coins by ruling princes, e.g., Mieszko III in Poland in 1173-1202 but economic effects were catastrophic because of a lack of money stability and difficulties to change these coins for foreign currencies (Cywinski, 1987). Oresme basing on Aristotle's view required a strong monetary policy as follows: "[...] a definite alteration of the weight or quantity of money without any change of name and value $[\ldots]$ such a change is plainly unlawful $[\ldots]$ ". He argued that " $[\ldots]$ because of these alterations, good merchandise or natural riches cease to be brought into a kingdom in which money is so changed, since merchants, other things being equal, prefer to pass over to those places in which they receive sound and good money" (Oresme, 1956, 1350s). Similarly, Kopernik argued that trade and other economic disturbances were connected with bad coins (Kopernik, 2001, 1926, 1528). In this way Aristotle's and Oresme's views could be considered as a basis of Kopernik's require- 
ments of strong money in Poland. Moreover Kopernik introduced the law mentioned in Introduction.

A damage of silver or gold money caused immediate inflation (not a higher inflation in the future) in usual political-economic terms. This situation limited government's activities in this sphere. Another reason of a high inflation was possible only on condition of bigger growth of gold suppliers than growth of other production. It occurred in $16^{\text {th }}$ century when enormous gold deliveries from America to Europe caused a high inflation in European states.

A radical change in the world monetary system was caused by banknotes which had not any real value. Costs to print banknotes are very low in comparison to their symbolic value. Moreover, people are usually not aware of money damage (Cywinski, 1986). An excessive printing of banknotes causes inflation in the longer period but people are usually not aware of its source.

\section{ECONOMIC REASONS OF BANKNOTES INCONVERTIBILITY INTO GOLD COINS}

A possibility to change banknotes for gold coins was important because of a low public trust to cotton or paper money. However, more and more banknotes in circulation caused an impossibility to convert them into gold in the longer time period. Therefore, many countries tried to limit a possibility to change their banknotes for gold. Especially economic disturbances caused embargo to convert banknotes into gold for central banks of many countries e.g. Germany and France during the World War I (Eichengreen, 2005).

Economic crisis and recession in 1929-1933 forced a suspension of British pound convertibility into gold and $31 \%$ pound depreciation in 1931 . The United States cancelled a convertibility of dollars into gold coins in 1933. Dollar was depreciated about $41 \%$ and there was established a new price of gold amounting 35 dollars for ounce (oz) (Cywinski, 1986). Gold 20-dollar coins containing 1oz weight and smaller gold coins were withdrawn from the circulation. It was connected with an attempt to overcome the crisis by printing more banknotes in the aim to stimulate demand and a growth of the economy according to the John Maynard Keynes's theory (Keynes, 2007, 1936).

There were attempts to establish exchange rates at the Bretton Woods Conference in 1944. However, the fixed (rigid) exchange rate system lets convert dollars into gold only for states. This system was disturbed by a suspension of dollar convertibility, named as Nixon shock in 1971. In consequence, the floating exchange rate system was introduced in March 1973 (see Staszczak, 2011). Since this time, instability of world currencies is a standard in the global monetary system.

Silver was relatively cheap in 1930s. Therefore, silver coins played only minor (secondary) role and they were not withdrawn from the circulation in 1933. Silver American dollars were minted since 1794 until 1935 and silver half dollars were minted until 1964. Since 1965 there were less silver in half dollar coins. There were 
only cheap metals in the U.S. quarter dollar, half dollar and one dollar coins in the 1970s. Nowadays, there is no silver dash in the U.S. dollars, except collectors' coins. Similar situation exists in Western European countries since the 1970s. This situation proves an occurrence to spoil money connected with a big inflation caused by the oil shocks.

On the contrary, silver coins nominated 200 zlotych were introduced into circulation in Poland during communist period in 1974-1976. It was exceptional event that could symbolize an advantage of the communist economy over capitalism in the recession after the first oil shock (see Staszczak, 2011). However, crisis in communist economies in 1980s proved inefficiency of central planed systems. In spite of this fact, there were also attempts to introduce silver coins into circulation in Poland in 1980s. However, these coins had a major importance for collectors. Usually, communist economies used banknotes and cheap coins, except collectors pieces, like market economies after 1970.

Moreover, exchange rates in communist countries were strictly regulated by governments. However, there existed also a black (illegal) market of foreign currencies. Usually, the communist currencies were to highly estimated according to the governments official exchange rates and to lowly in a black market. It was connected with a relatively difficult attempt to foreign currencies in the communist countries.

A quite different situation is in the People Republic of China. The communist system in this country was reformed in 1990s and transformed into the better efficiency. Nowadays, Chinese impressive economic growth is possible thanks to a low labor costs and governments control over capital flows which limit opportunities for financial speculations. China is not interested in advantages based on financial manipulations (Ying, 2011). In spite of the official communist ideology China has a partially planned and partially market economy. A lack of a free market convertibility of yuan is helpful to maintain a surplus in Chinese foreign trade balance because of the relatively low official yuan exchange rate (Staszczak, 2012). However, a slow yuan growth proves a strong international position of Chinese economy.

A break of connections between money and gold is a major reason of the growing instability of world currencies. Many countries are interested to have relatively cheap currency because of competitiveness in their foreign trade (Staszczak, 2012). Therefore, the world currencies were more instable after Nixon shock, i.e., so called suspension (and real cancellation) of the U.S. dollar convertibility into gold in international relations in 1971 (a direct dollar convertibility into gold coins was cancelled in 1933). There were two agreed U.S. dollars depreciations in 1971-1973, i.e., before the establishment of the flexible exchange rate system (Coffey, 1974; Johnson, 1988). This system is existing since March 1973 till now. A high inflation until the end of 1970s connected with two oil shock and economic recessions (see Staszczak, 2011) should cause a change of the monetary policy. Fed announced a major change in monetary policy in October 1979. However, the growth of money supply into the economy was limited but continued in early 1980s. Milton Friedman and other monetarists criticized Fed. They argued "that the Fed should 
keep the growth of money constantly and should not change its targets frequently (Dornbusch \& Fischer, 1987).

More radical proposal was considered by the U.S. President Ronald Reagan who appointed a Gold Commission in 1981 to consider a return to the gold standard. This solution would prevent authorities from pumping too much dollars into the circulation. However, critics of this solution argued that a market economy was inherently unstable and therefore, the monetary authorities should be able to change money supply into the economy according to the situation. Finally, a return to the gold standard was not recommended by the Gold Commission. There was a danger that world gold supply rose slowly at about $2 \%$ per year and it was not enough according to the growth of other production. Moreover, a demand for gold would be higher (McConnell, 1987). Summarizing, there is a little probably return to the gold standard. Firstly, there are no enough gold stores over the world and therefore, a return of circulated gold coins must cause a growth of this metal prices. Secondly, the gold money make impossible a controlled inflation characteristic for all contemporary economies over the world basing on printing banknotes.

Banknotes give opportunities for central banks to credit governments in spite of a lack of real money, i.e., money covered in real products like former coins minted in gold. Further depreciation of money will probably make possible to return the governments debts. If not there will be next possibilities of credits made in new printing banknotes. Foreign credits make another situation that depends on currency of credit. If foreign credit was given in debtor country currency it could be a foreign help in real terms, e.g., the U.S. bonds in the beginning of Reaganomics was sold in expensive dollars but many years later they were rebought by the U.S. government in cheaper (depreciated) dollars because of overprinting of American currency. When European Central Bank bought Greece or Spanish bonds it meant cheaper euro connected with its necessary depreciation because of excessive printing, i.e., a lost of other euro zone countries. Foreign credits in foreign currencies were usually very difficult for countries in debts because they could not return money in their own depreciated currencies. Such problems had emerging economies of South Eastern Asia which were in debts and dependent on foreign capital flows during the crisis of 1997-1998 because of a lack of enough reserves of foreign currencies. A currency mismatch conducted to a loss of countries liquidity (Park, 2011). Similar situations were in Poland and other communist countries that went into bankruptcy in the 1980s because of debts in foreign currencies. Problems with liquidity in Ukraine forced the Ukrainian Central Bank to require form exporters to sell a half of their foreign currencies obtained since November 2012.

An important event in flexible exchange rates system was the entry of euro into the global monetary system in 1999 (electronic version) and in 2002 (banknotes and coins). Euro replaced many national currencies in Europe. However, a lack of euro gold standard and the crisis in euro zone, especially in Greece, Spain, Portugal, Ireland and Italy, etc. create big difficulties for a stability of this currency. 


\begin{tabular}{|c|c|c|}
\hline 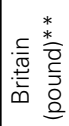 & 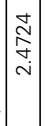 & 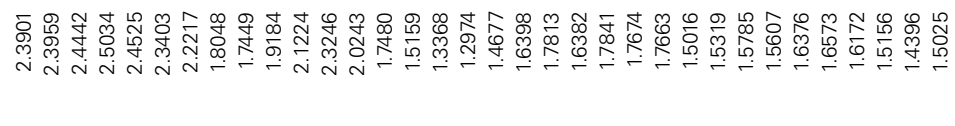 \\
\hline 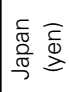 & 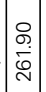 & 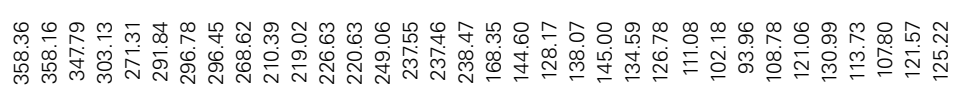 \\
\hline 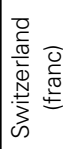 & 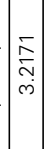 & 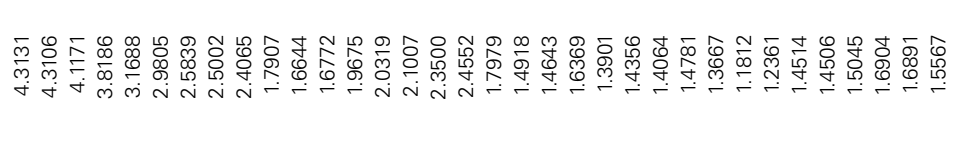 \\
\hline 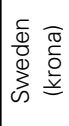 & 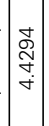 & 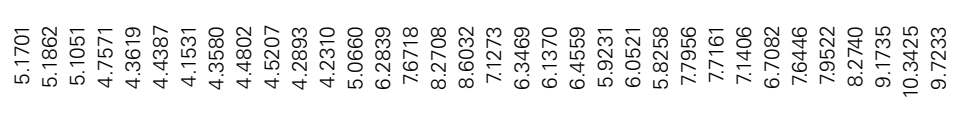 \\
\hline 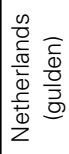 & 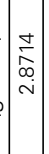 & 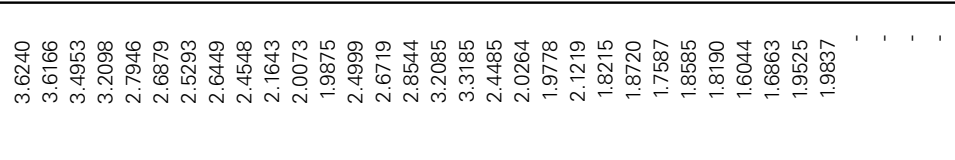 \\
\hline 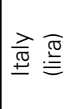 & $\begin{array}{l}f \\
\infty \\
\infty \\
0 \\
\infty \\
0\end{array}$ & 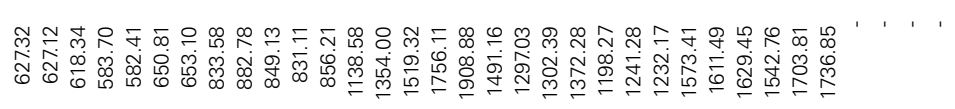 \\
\hline 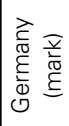 & 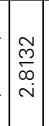 & 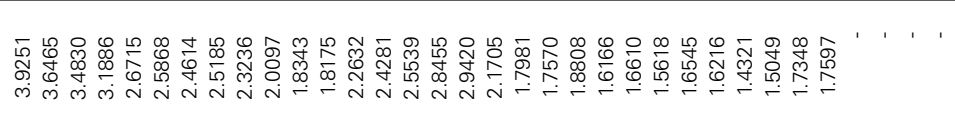 \\
\hline 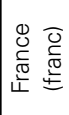 & 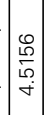 & 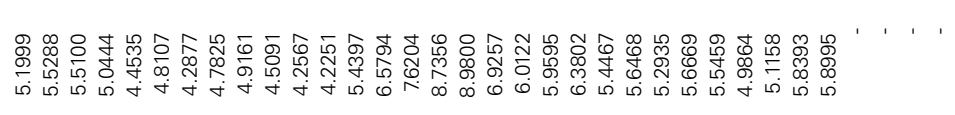 \\
\hline 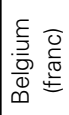 & 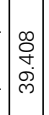 & 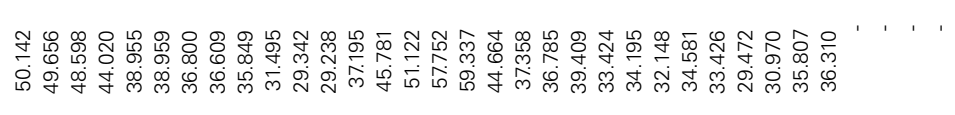 \\
\hline 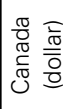 & 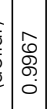 & 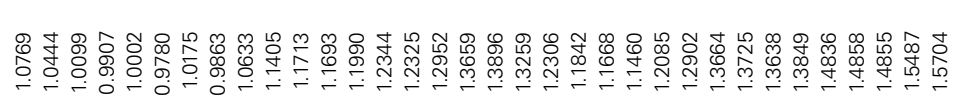 \\
\hline 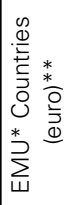 & 1 & 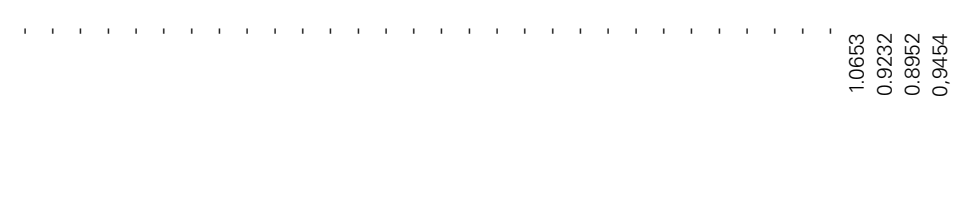 \\
\hline$\frac{\overline{0}}{\frac{0}{0}}$ & 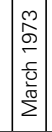 & 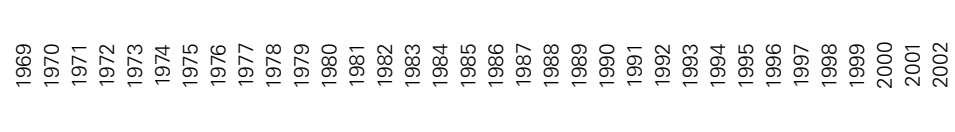 \\
\hline
\end{tabular}




\section{INSTABILITY OF EXCHANGE RATES AFTER THE GOLD STANDARD}

International exchange rates depends on the real supply and demand for particular currencies connected with international trade and capital flows. Speculations and interest rates, governments bonds and interventions of central banks play also an important role.

Therefore, there is important to analyze instabilities of the world major currencies since March 1973 until 1998, i.e., the last year before the entrance of euro into circulation.

During that 25-year period there were some relatively strong and weak currencies. According to presented point of view the strong currencies were those ones that exchange rates rose, i.e., that quantity of currency units per U.S. dollar dropped, e.g. Swiss franc $(-55 \%$ - i.e., there were $55 \%$ less Swiss franc units per U.S. dollar in 1998 than in March 1973), Japanese yen (-50\%), German mark (-37\%), Dutch gulden $(-31 \%)$ and Belgian franc $(-8 \%)$. The weak currencies were those ones that exchange rates fell, i.e., the volume of currency units per U.S. dollar rose, e.g., Italian lira $(206 \%$ - i.e., there were $206 \%$ more Italian lira units per U.S. dollar in 1998 than in March 1973), Swedish krona (80\%), British pound (49\%), Canadian dollar $(49 \%)$, and French franc (31\%), (Table 2).

Table 2: Nominal and percentage changes of U.S. dollar exchange rates in major world currencies in March 1973 - 1998

(Nominal changes: exchange rates in 1998 minus exchange rates in March 1973)

(Percentage changes: nominal changes as a percent of nominal exchange rates in March 1973;

March $1973=100 \%$ )

\begin{tabular}{|l|c|c|}
\hline \multicolumn{1}{|c|}{ Country (currency) } & Nominal changes & Percentage changes \\
\hline Britain (pound) & 0.1989 & -8 \\
\hline Belgium (franc) & -3.098 & 49 \\
\hline Canada (dollar) & 0.4869 & 31 \\
\hline France (franc) & 1.3839 & -37 \\
\hline Germany (mark) & -1.0535 & 206 \\
\hline Italy (lira) & 1168.68 & -50 \\
\hline Japan (yen) & -130.91 & -31 \\
\hline Netherlands (gulden) & -0.8877 & 80 \\
\hline Sweden (krona) & 3.5228 & -55 \\
\hline Switzerland (franc) & -1.7665 & . \\
\hline
\end{tabular}

Note: British pound is showed like all other currencies, i.e. British pound units per U.S. dollar, that amounts to 0.6034 in 1998 and 0.4045 in March 1973.

Source: Author's calculations according to Table 1. 


\section{Response for the oil shocks}

Oil shocks in 1973-1974 and 1979-1980 caused the two global recessions. The U.S.A. applied a policy of American dollar depreciation realized by an excessive printing and a supply of money into the circulation. It meant that Americans paid more dollars per oil barrels but they used chipper (worse) dollars (Coffey, 1974; Ikenberry, 1988; Johnson, 1991; Staszczak, 2011).

Table 3: Nominal and percentage changes of U.S. dollar exchange rates in major world currencies in March 1973 - 1980

(Nominal changes: exchange rates in 1980 minus exchange rates in March 1973)

(Percentage changes: nominal changes as a percent of nominal exchange rates in March 1973; March 1973 = 100\%)

\begin{tabular}{|l|c|c|}
\hline \multicolumn{1}{|c|}{ Country (currency) } & Nominal changes & Percentage changes \\
\hline Britain (pound) & 0.0257162 & 6 \\
\hline Belgium (franc) & -10.17 & -26 \\
\hline Canada (dollar) & 0.1726 & 16 \\
\hline France (franc) & -0.2905 & -6 \\
\hline Germany (mark) & -0.9957 & -35 \\
\hline Italy (lira) & 288.04 & 51 \\
\hline Japan (yen) & -35.27 & -13 \\
\hline Netherlands (gulden) & -0.8839 & -31 \\
\hline Sweden (krona) & -0.1984 & -4 \\
\hline Switzerland (franc) & -1.5399 & -48 \\
\hline
\end{tabular}

Note: British pound is showed like all other currencies, i.e., British pound units per U.S. dollar, that amounts to 0.4301815 in 1980 and 0.4044653 in March 1973.

Source: Author's calculations according to Table 1.

Therefore, the U.S. dollar was depreciated versus most major currencies in 1973-1980. The strongest currency in that period was Swiss franc $(-48 \%$ - there were 48\% less Swiss franc units per U.S. dollar in 1980 than in March 1973). Other strong currencies that exchange rates rose versus the U.S. dollar were as follows: German mark (-35\%), Dutch gulden $(-31 \%)$, and Belgian franc $(-26 \%)$. Currencies little better than U.S. dollar were as follows: Japanese yen $(-13 \%)$, French franc $(-6 \%)$, and Swedish krona $(-4 \%)$. Japanese authorities influenced yen exchange rate in the aim to maintain the international competitiveness of the country economy. Currencies worse than the U.S. dollar were as follows: Italian lira (51\% - there were 51\% more Italian lira units per U.S. dollar in 1980 than in March 1973), Canadian dollar (16\%), and British pound (6\%), (Table 3).

\section{U.S. dollar appreciation during the first part of Reaganomics}

During the first part of Ronald Reagan's economic policy the U.S. dollar was appreciated versus all major currencies over the world. It was connected with con- 
cerns about the U.S. dollar lost of the position of the most important currency over the world (Staszczak 2001, Staszczak 2011).

In this way all major world currencies were weaker versus the U.S. dollar as follows: Italian lira $(123 \%$ - there were $123 \%$ more Italian lira units per U.S. dollar in 1985 than in 1980), French franc (113\%), Swedish krona (103\%), Belgian franc $(102 \%)$, British pound $(79 \%)$, Dutch gulden $(67 \%)$, German mark $(62 \%)$, Swiss franc (46\%), Canadian dollar (17\%), and Japanese yen $(5 \%)$, (Table 4). A relatively low depreciation of Japanese yen proves the thesis about authorities financial activities which reduced excessive hesitations of this currency.

Table 4: Nominal and percentage changes of U.S. dollar exchange rates in major world currencies in $1980-1985$

(Nominal changes: exchange rates in 1985 minus exchange rates in 1980)

(Percentage changes: nominal changes as a percent of nominal exchange rates in1980; $1980=100 \%$ )

\begin{tabular}{|l|c|c|}
\hline \multicolumn{1}{|c|}{ Country (currency) } & Nominal changes & Percentage changes \\
\hline Britain (pound) & 0.3405908 & 79 \\
\hline Belgium (franc) & 30.099 & 102 \\
\hline Canada (dollar) & 0.1966 & 17 \\
\hline France (franc) & 4.7579 & 113 \\
\hline Germany (mark) & 1.1245 & 62 \\
\hline Italy (lira) & 1052.67 & 123 \\
\hline Japan (yen) & 11.84 & 5 \\
\hline Netherlands (gulden) & 1.3310 & 67 \\
\hline Sweden (krona) & 4.3722 & 103 \\
\hline Switzerland (franc) & 0.7780 & 46 \\
\hline
\end{tabular}

Note: British pound is showed like all other currencies, i.e., British pound units per U.S. dollar, that amounts to 0.7707723 in 1985 and 0.4301815 in 1980.

Source: Author's calculations according to Table 1.

\section{U.S. dollar slow depreciation during the second part of Reaganomics}

The U.S. dollar appreciation played a positive role for the U.S. economy until 1983 when deficit on American foreign trade balance was relatively low. However, since 1984 deficit on the U.S. foreign trade balance exceeded 100 billion dollars and the U.S. economy was in deep debts (Economic, 1996; Staszczak, 2001). Therefore, since 1985 the U.S. dollar was slowly depreciated.

During the period 1985-1989 all major currencies were stronger than the U.S. dollar. The strongest currency was Japanese yen $(-42 \%$ — there were $42 \%$ less Japanese yen unites per U.S. dollar in 1989 than in 1985). Other exchange rates versus U.S. dollar also rose follows: German mark (-36\%), Dutch gulden (-36\%), Belgian franc $(-34 \%)$, Swiss franc $(-33 \%)$, French franc $(-29 \%)$, Swedish krona $(-25 \%)$, British pound $(-21 \%)$, Italian lira $(-21 \%)$, and Canadian dollar $(-14 \%)$, (Table 5). 
Table 5: Nominal and percentage changes of U.S. dollar exchange rates in major world currencies in $1985-1989$

(Nominal changes: exchange rates in 1989 minus exchange rates in 1985.

(Percentage changes: nominal changes as a percent of nominal exchange rates in 1985; $1985=100 \%$ )

\begin{tabular}{|l|c|c|}
\hline \multicolumn{1}{|c|}{ Country (currency) } & Nominal changes & Percentage changes \\
\hline Britain (pound) & -0.1603463 & -21 \\
\hline Belgium (franc) & -19.928 & -34 \\
\hline Canada (dollar) & -0.1853 & -14 \\
\hline France (franc) & -2.5998 & -29 \\
\hline Germany (mark) & -1.0612 & -36 \\
\hline Italy (lira) & -536.60 & -21 \\
\hline Japan (yen) & -100.40 & -42 \\
\hline Netherlands (gulden) & -1.1966 & -36 \\
\hline Sweden (krona) & -2.1473 & -25 \\
\hline Switzerland (franc) & -0.8183 & -33 \\
\hline
\end{tabular}

Note: British pound is showed like all other currencies, i.e., British pound units per U.S. dollar, that amounts to 0.610426 in 1989 and 0.7707723 in 1985.

Source: Author's calculations according to Table 1.

\section{World currencies during the global hegemony transformation}

The hegemony transformation started in 1989-1991 when the Soviet bloc and the Soviet Union collapsed. It meant a single American hegemony. However, the U.S.A. were not able to maintain the exclusive hegemony and in the mid 1990s the world system transformed into the global collective hegemony of state-powers and transnational corporations according to the state-corporation hegemonic stability theory (see Staszczak 2011). In 1989-1998 the U.S. dollar was a relatively cheap currency.

Table 6: Nominal and percentage changes of U.S. dollar exchange rates in major world currencies in $1989-1998$

(Nominal changes: exchange rates in 1998 minus exchange rates in 1989.

(Percentage changes: nominal changes as a percent of nominal exchange rates in1989; $1989=100 \%$ )

\begin{tabular}{|l|c|c|}
\hline \multicolumn{1}{|c|}{ Country (currency) } & Nominal changes & Percentage changes \\
\hline Britain (pound) & $-0,007035$ & 1 \\
\hline Belgium (franc) & -3.099 & -8 \\
\hline Canada (dollar) & 0.29928 & 25 \\
\hline France (franc) & -0.4807 & -8 \\
\hline Germany (mark) & -0.1211 & -6 \\
\hline Italy (lira) & 364.57 & 27 \\
\hline Japan (yen) & -7.08 & -5 \\
\hline Netherlands (gulden) & -0.1382 & -7 \\
\hline Sweden (krona) & 1.4963 & 23 \\
\hline Switzerland (franc) & -0.1863 & -11 \\
\hline
\end{tabular}

Note: British pound is showed like all other currencies, i.e., British pound units per U.S. dollar, that amounts to 0.603391 in 1998 and 0.610426 in 1989.

Source: Author's calculations according to Table 1. 
Some major currencies were little stronger than U.S. dollar in the mentioned period as follows: Swiss franc $(-11 \%$ - there were $11 \%$ less Swiss franc units per U.S. dollar in 1998 than in 1989), Belgian franc (-8\%), Dutch gulden (-7\%), German mark (-6\%), and Japanese yen $(-5 \%)$. There were also some weaker currencies than U.S. dollar as follows: Italian lira $(27 \%$ - there were $27 \%$ more Italian lira units per U.S. dollar in 1998 than in 1989), Canadian dollar (25\%), Swedish krona $(23 \%)$, and British pound $(1 \%)$, (Table 6$)$. This data proves a relative stabilization of the world financial system before euro entrance into the circulation.

\section{INSTABILITY OF EXCHANGE RATES AFTER EURO ENTRANCE INTO THE CIRCULATION}

Euro replaced national currencies in the following European countries: Austria, Belgium, France, Finland, Germany, Ireland, Italy, Luxembourg, Netherlands, Portugal and Spain in 1999, Greece in 2001, Slovenia in 2007, Cyprus and Malta in 2008, Slovakia in 2009 and Estonia in 2011. Euro was introduced in electronic version in 1999 and in banknotes and coins in 2002. Initially, a lack of confidence to the new currency influenced the growth of the U.S. dollar versus euro since 1.0653 U.S. dollar units per euro in 1999 to 0.8952 U.S. dollar units per euro in 2001 (Table 7).

After these fears euro exchange rate versus U.S. dollar rose since 0.8952 U.S. dollar units per euro in 2001 to 1.4726 U.S. dollar units per euro in 2008 and it was connected with the U.S. dollar depreciation period. During the U.S. dollar appreciation period there were a little drop and a relative stabilization of euro exchange rate amounting 1.3931 U.S. dollar units per euro in 2011 (Table 7).

In 1999-2011 all major currencies, except Mexican peso were some stronger than U.S. dollar. It means that their exchange rates versus U.S. dollar rose, i.e., that quantity of currency units per U.S. dollar dropped, e.g. Swiss franc $(-41 \%-$ i.e., there were 41\% less Swiss franc units per U.S. dollar in 2011 than in 1999), Australian dollar (-38\%), Canadian dollar (-33\%), Japanese yen (-30\%), euro (-24\%), Chinese yuan named renminbi (-22), Swedish krona (-22\%), South Korean won $(-7 \%)$, British pound $(-1 \%)$. Only Mexican peso was weaker currency than U.S. dollar in this period, i.e., that volume of peso units per U.S. dollar rose $(30 \%$ - i.e., there were 30\% more Mexican pesos per U.S. dollar in 2011 than in 1999). Polish zloty was little appreciated versus euro $(-7 \%$ - there were $7 \%$ less Polish zloty units per euro in 2011 than in 1999, (Table 8). Since euro entrance Economic Report of the President adds Canadian dollar, Chinese yuan, Mexican peso, and South Korean won to most important currencies. 


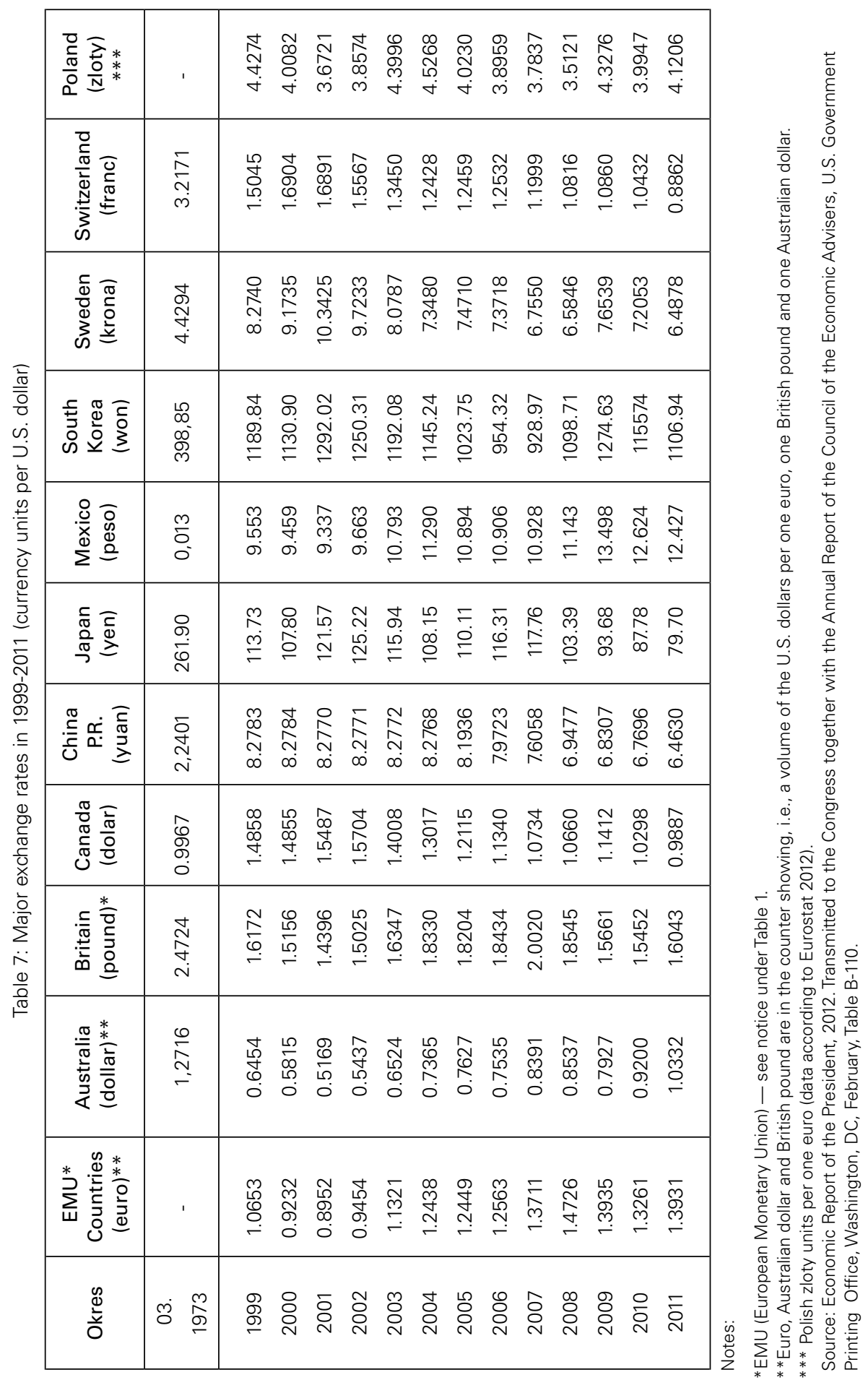


Table 8: Nominal and percentage changes of U.S. dollar exchange rates

in major world currencies in 1999 - 2011

(Nominal changes: exchange rates in 2011 minus exchange rates in 1999)

(Percentage changes: nominal changes as a percent of nominal exchange rates in 1999; 1999 year $=100 \%$ )

\begin{tabular}{|l|l|c|}
\hline \multicolumn{1}{|c|}{ Country (currency) } & Nominal changes & Percentage changes \\
\hline EMU (euro) & -0.2208791 & -24 \\
\hline Australia (dollar) & -0.5815599 & -38 \\
\hline Britain (pound) & -0.00497214 & -1 \\
\hline Canada (dollar) & -0.4971 & -33 \\
\hline China P.R. (yuan) & -1.8153 & -22 \\
\hline Japan (yen) & -34.03 & -30 \\
\hline Mexico (peso) & 2.874 & 30 \\
\hline South Korea (won) & -82.9 & -7 \\
\hline Sweden (krona) & -1.7862 & -22 \\
\hline Switzerland (franc) & -0.6183 & -41 \\
\hline Poland (zloty) ${ }^{* *}$ & -0.3068 & -7 \\
\hline
\end{tabular}

Notes: Euro, British pound and Australian dollar are showed like all other currencies, i.e., euro units per U.S. dollar that amounts to 0.7178235 in 2011 and 0.9387027 in 1999; Australian dollar units per U.S. dollar that amounts to 0.9678668 in 2011 and 1.5494267 in 1999; British pound units per U.S. dollar that amounts to 0.62332480 in 2011 and 0.6183527 in 1999.

***Polish zloty exchange rate versus euro, i.e., Polish zloty units per euro.

Source: Author's calculations according to Table 7.

\section{U.S. dollar depreciation period}

There is important to share the above mentioned period 1999-2011 for two periods. First concerns the U.S. dollar depreciation and second touches the U.S. dollar appreciation. In 1999-2008 the U.S. dollar was depreciated versus all most important currencies except Mexican peso. However, only European currencies, i.e. euro, British pound, and Swedish krona (except Swiss franc), and in a little scale South Korean won appreciated versus U.S. dollar more in 1999-2008 than in a whole period 1999-2011, i.e., including a period of the U.S. dollar appreciation in 2008-2011 (compare Table 8 and Table 9).

The strongest currencies in 1999-2008 were as follows: euro (-28\% - there were $28 \%$ less euro units per U.S. dollar in 2008 than in 1999; and it was more than in all period 1999-2011 when the change amounted -24\%), Canadian dollar $(-28 \%)$, Swiss franc $(-28 \%)$, Swedish krona $(-25 \%)$, Australian dollar $(-24 \%)$, Chinese yuan $(-16 \%)$, British pound $(-13 \%)$, Japanese yen $(-9 \%)$, and South Korean won $(-8 \%)$. Only Mexican peso exchange rate dropped versus U.S. dollar (17\% - there were 17\% more Mexican peso units per U.S. dollar in 2008 than in 1999). There is interesting that Polish zloty appreciated versus euro $(-21 \%$ - there were $21 \%$ less Polish zloty units per euro in 2008 than in 1999) in spite that euro, Canadian dollar and Swiss franc were the strongest most important currencies over the world in that period. According to this point of view Polish zloty was stronger 
than all most important currencies over the world, (Table 9). However, a big depreciation of Polish zloty in 2008-2011 proved a strong dependence of this currency on international speculative capital flows.

Table 9: Nominal and percentage changes of U.S. dollar exchange rates

in major world currencies in $1999-2008$

(Nominal changes: exchange rates in 2008 minus exchange rates in 1999)

(Percentage changes: nominal changes as a percent of nominal exchange rates in 1999; $1999=100 \%$ )

\begin{tabular}{|l|c|c|}
\hline Country (currency) & Nominal changes & Percentage changes \\
\hline EMU (euro) & -0.2596316 & -28 \\
\hline Australia (dollar) & -0.3778953 & -24 \\
\hline Britain (pound) & -0.0791237 & -13 \\
\hline Canada (dollar) & -0.4198 & -28 \\
\hline China P.R. (yuan) & -1.3306 & -16 \\
\hline Japan (yen) & -10.34 & -9 \\
\hline Mexico (peso) & 1.59 & 17 \\
\hline South Korea (won) & -91.13 & -8 \\
\hline Sweden (krona) & -21.894 & -25 \\
\hline Switzerland (franc) & -0.4229 & -28 \\
\hline Poland (zloty)*** & -0.9153 & -21 \\
\hline
\end{tabular}

Notes: Euro, British pound and Australian dollar are showed like all other currencies, i.e. euro units per U.S. dollar that amounts to 0.679071 in 2008 and 0.9387027 in 1999; Australian dollar units per U.S. dollar that amounts to 1.1713717 in 2008 and 1.5494267 in 1999; British pound units per U.S. dollar that amounts to 0.5392289 in 2008 and 0.6183527 in 1999.

***Polish zloty exchange rate versus euro, i.e., Polish zloty units per euro.

Source: Author's calculations according to Table 7.

\section{U.S. dollar reinforcement}

The U.S. dollar reinforcement in 2008-2011 concerned only the following currencies that were weaker than American currency: British pound $(16 \%$ - there were $16 \%$ more British pound units per U.S. dollar in 2011 than in 2008), Mexican peso $(12 \%)$, euro $(6 \%)$, and South Korean won $(1 \%)$. Therefore, this reinforcement had a limited range and was connected with a weakness of above mentioned economies, especially with economic crisis in euro area. The U.S. dollar was depreciated versus the following currencies: Japanese yen $(-23 \%$ - there were $23 \%$ less Japanese yen units per U.S. dollar in 2011 than in 2008), Swiss franc $(-18 \%)$, Australian dollar (-17\%), Chinese yuan (-7\%), Canadian dollar (-7\%), and Swedish krona $(-1 \%)$, (Table 10$)$. This situation proves a weakness of the U.S. dollar and problems of many European and other economies which need cheap currencies to improve their competitiveness in foreign trade. Speculations of exchange rates are also important. Polish zloty depreciated strongly versus euro $(17 \%$ - there were $17 \%$ more Polish zloty units per euro in 2011 than in 2008) in spite of euro weakness in comparison to U.S. dollar and many other most important currencies, 
(Table 10). It confirms the thesis about strong influences of international speculative capital flows on Polish zloty and proves not too good position of Poland in the world economy.

Table 10: Nominal and percentage changes of U.S. dollar exchange rates in major world currencies in March 2008 - 2011

(Nominal changes: exchange rates in 2011 minus exchange rates in 2008)

(Percentage changes: nominal changes as a percent of nominal exchange rates in 2008; $2008=100 \%$ )

\begin{tabular}{|l|c|c|}
\hline \multicolumn{1}{|c|}{ Country (currency) } & Nominal changes & Percentage changes \\
\hline EMU (euro) & 0.0387525 & -17 \\
\hline Australia (dollar) & -0.2035048 & 16 \\
\hline Britain (pound) & 0.0840959 & -7 \\
\hline Canada (dollar) & -0.0793 & -7 \\
\hline China P.R. (yuan) & -0.4847 & -23 \\
\hline Japan (yen) & -23.69 & 12 \\
\hline Mexico (peso) & 1.284 & 1 \\
\hline South Korea (won) & 8.23 & -1 \\
\hline Sweden (krona) & -0.0968 & -18 \\
\hline Switzerland (franc) & -0.1996 & 17 \\
\hline Poland (zloty)*** & 0.6085 & 6 \\
\hline
\end{tabular}

Notes: Euro, British pound and Australian dollar are showed like all other currencies, i.e., euro units per U.S. dollar that amounts to 0.7178235 in 2011 and 0.679071 in 2008; Australian dollar units per U.S. dollar that amounts to 0.9678668 in 2011 and 1.1713717 in 2008; British pound units per U.S. dollar that amounts to 0.62332480 in 2011 and 0.5392289 in 2008

***Polish zloty exchange rate versus euro, i.e., Polish zloty units per euro.

Source: Author's calculations according to Table 7.

\section{DISCUSSIONS OVER INSTABILITY OF THE CONTEMPORARY WORLD CURRENCIES}

The indicated above changes in exchange rates in 1973-2011 prove the enormous instability of the contemporary world currencies. A lack of the gold standard causes the growth of the global instability. Therefore, it is important to discuss proposals to improve the world monetary system.

Andrea Terzi (2005) looks causes of the instabilities in "an interaction between a crisis in confidence of the official parity of the currency and a crisis of confidence in its banking system [...]”. She underlines a core-periphery structure of the global economy and suggests a diversification of the world currencies, i.e., to recognize "the quality of key currencies that function as vehicles of payments across borders, and other (soft) currencies that are less, or not at all, acceptable in international transactions". She supports the idea of John Maynard Keynes $(2007,1936)$ that currencies are differ in terms of their liquidity premium. Therefore, she suggests a 
"dollarization" (i.e., the U.S. dollar as a major world currency) or currency blocs of supra-national currencies or a single world money. She argues that according to Keynes's assumptions "that monetary side of the global economy is not a neutral factor" and that different categories of the world currencies "should be considered as one of the fundamental factors behind any model of financial instability" (Terzi, 2005).

However American and European big debts and crisis prove the error of this hierarchy. Terzi does not see a real weakness of the U.S. dollar, euro and other important global currencies in longer time period that is connected with a lack of the gold standard. The U.S. dollar and euro are the most important currencies because of big areas of their circulation. Moreover, world prices of oil are indicated in the U.S. dollars. However, I prove in the fourth and fifth sections (i.e., the analysis of Tables 1-10) that nor the U.S. dollar either euro are not any highest quality currencies. Other currencies, e.g. Swiss franc and Japanese yen presented better changes in exchange rates than the U.S. dollar and euro in may periods. However, these currencies cannot replace U.S. dollar and euro as the most important pillars of the international monetary system because they are used in relative small territories. A changing world demand (including a speculative demand) for these currencies (especially for Swiss franc) can cause enormous hesitations of their exchange rates, e.g., a big growth of Swiss frank exchange rate in 2010. Therefore, there is necessary to add Chinese yuan to the triad of the most important currencies over the world because of the enormous importance of China in the global economy. Other important currencies should supplement the world monetary system both currencies acknowledged nowadays, i.e., mentioned in the fifth section, Tables 7-10 and other ones of emerging economies, e.g., Argentinian peso, Brazilian real, Indian rupee, Russian ruble, South African rand, etc.

Milton Friedman (1953) claims that internal prices and wages are less flexible down than exchange rates. Therefore, a low flexibility of prices and wages distorts their adjustment to the highly flexible exchange rates and conducts to deficits in foreign trade balances. In this way, he suggests the economic policy forcing a decline of prices and wages in spite an increase of unemployment in the aim to offset the incipient deficits. He argues as follows: "The consequent decline in real income reduces domestic demand for foreign goods and thus demand for foreign currency with which to purchase these goods". However, such a policy causes the recession and is little effective. Moreover, there is no any guaranty of the adjustments. Speculative demand for foreign currencies is not connected with a demand for foreign goods. Therefore, the adjustments are not often achieved. Central banks have also many opportunities for interventions in their own currencies that have not any fixed parity versus gold, e.g., Swiss Central Bank could effective influence depreciation od franc versus euro and U.S. dollar in September 2011. It would be more difficultly and costly during the gold parity. Of course, after fast and high growth of the gold prices a correction of these metal prices was inescapable. However, a growth of the gold prices is unavoidable in the long run versus all contemporary currencies over the world. 
An interesting discussion concerning unstable exchange rates presents Paul Krugman (2002) who criticizes Friedman's arguments "that profit-maximizing speculators would always tend to stabilize, not destabilize, the exchange rate". He claims that since 1973 "yearly changes in exchange rates have been much larger than can be explained by differences in inflation rates or in other variables such as different growth rates in various countries' money supplies". Rudiger Dornbusch (1976) also assumes that exchange rates and asset markets adjust faster than goods markets. Capital flows (i.e. the both foreign direct investments and speculative financial flows) influence exchange rates because of a creation of demand or supply for particular currencies. Speculative flows are more danger for the exchange rates stability because of their unforeseeable character (Staszczak, 2012). A lack of enough control over international capital flows and bank activities creates the global financial instability (Reszat, 1999).

I fully agree with Krugman's (2002) thesis as follows: “Taking the long view, however, attitudes about exchange rate instability have repeatedly shifted, proving ultimately as poorly grounded in fundamentals as the rates themselves". In my opinion Friedman's view was adopted to the world monetary system, in spite of its inadequacy, because of too small stores of gold in the U.S.A. to stabilize the Bretton Woods system of fixed (rigid) exchange rates. Therefore, his explanation was correct politically and applied because of a lack of another solution. In addition, Friedman's theory was useful after the recessions and high inflation in the 1970s, i.e., during Reaganomics in 1981-1989. However, the positive effects of monetarism for American economy were possible because of the U.S. dollar's position of the most important currency over the world, e.g., world oil prices were valuated in this currency and foreign capital invested in the U.S.A. to obtain strong American dollars (Staszczak, 2004, 2001). Monetarism applied in other countries caused worse economic situation, e.g., economic reforms in Poland after communism collapse in 1989 conducted to a great unemployment and almost liquidation of the country's industry, i.e., bankruptcies of many state's factories. Moreover, Polish zloty exchange rate is still strongly dependent on foreign (especially speculative) capital flows (see Tables: 7, 8, 9, 10).

\section{PERSPECTIVES FOR THE WORLD MONETARY SYSTEM}

A lack of the gold standard promotes influences of authorities, central banks, and speculators on exchange rates. The global economic crisis and recessions in 2008-2009 and started in 2011 caused a limitation of the world demand. Therefore, many countries have problems with their foreign trade balance. Cheap currencies mean lower prices in international markets. Therefore, many countries try to depreciate their currencies (Staszczak, 2012). Speculations on currencies and on non material capital flows also influence exchange rates significantly.

Moreover, a decision concerning the new world monetary system would must be agreed within the global collective hegemony of state-powers and transnational 
corporations according to the state-corporation hegemonic stability theory (Staszczak, 2011). However, there are no plans to return to the gold standard in scenarios of the future of the international monetary system elaborated by the World Economic Forum. There is a historical overview of the gold standard and information about a deflationary spiral and a collapse of the system during the Great Depression. There were also other problems, i.e., speculation attacks connected with a fact that not all countries used the gold standard in the 1920s (Schwab, 2012). Therefore, discussions about the gold standard would be academic only.

A relative stabilization of the world monetary system without the gold standard is necessary to improve the global economy and it should be the common target of the collective global hegemony, except corporations interested in speculative profits mostly. Instability of the contemporary world currencies impedes to overcome the recession because it causes a growth of uncertainties in the international trade and long term investments. However, there are many contradictory interests inside and outside the hegemony which handicap a common action as follows:

1. Conflicts between the ideological Western part of the hegemony (i.e., the U.S.A., Britain, France) and China and Russia connected with a struggle for the political leadership and economic advantages;

2. Economic conflicts inside the ideological West connected with advantages achieved from the international trade;

3. Conflicts of interests between states and corporations parts of the hegemony connected with states attempts to control over activities of transnational corporations, including banks;

4. Social protests against the hegemony activities in the hegemonic state powers and in other countries over the world;

5. Contradictory interests between the global collective hegemony and less developed countries connected with political reasons and advantages achieved from the world commerce and capital flows (see Staszczak, 2011 and 2012).

In spite of the above mentioned difficulties, a realistic discussion about the future of the international monetary system must allow for the alternative scenarios of its development elaborated by the global collective hegemony (i.e., politicians ruling the state-powers and owners of major transnational corporations). Scenarios of the World Economic Forum include a sentence that confirms the state-corporation hegemonic stability theory (Staszczak, 2011) as follows: "Analyzing such alternative developments is critical to both public and private sector decision-makers for building robust and resilient strategies - not only to anticipate and prepare for the possible future shifts that may affect them, but also to take stakeholders focus on what steps must be taken today to work towards a desired outcome" (Schwab, 2012). It proves a key importance of politicians and owner of 
transnational corporations, i.e., the global collective hegemony of state-powers and major transnational corporations for shaping of the world system changes (Staszczak, 2011). There are three perspectives for the world monetary system in 2030 as follows:

1. Regionalism connected with a drop of global trade and capital flows which will force a growth of importance of policy turned inward and regional economic connections;

2. Global imbalances connected with European debt crisis and a probable decrease of euro area, i.e., unilateral break from euro by Greece, etc., reforms in the U.S.A. and China; and pressures on a sustainability of natural resources;

3. Two-speed world connected with possible different fiscal solutions and effects in the U.S.A. and Europe, and growing importance of yuan in trade among emerging markets (Schwab, 2012).

In my opinion, there are many difficulties to discuss about the global situation in 2030 because of many factors which are unknown nowadays or can be changed unforeseeably, e.g., a situation in some emerging countries like Brazil, India, Iran, etc. Twenty years ago China was less important part of the global economy than nowadays. Therefore, the plans should be made carefully.

A possibility to replace the U.S. dollar and euro by Chinese yuan on the position of the major world currency would be a difficult and little probable attempt because many financial institutions over the world use these currencies. More probably is an introduction of yuan as the third major global currency together with the U.S. dollar and euro. China is an enormous country and therefore, yuan is an abundant currency that is less liable to speculations than currencies of smaller countries. Moreover, Chinese economic potential and growth, foreign trade surplus (Eurostat, 2012) and enormous gold reserves (Chu, 2009) promote such a solution. In any case yuan direct and non limited convertibility for the gold is little probable in the contemporary global terms. Therefore, Chinese currency can stabilize the global financial system in a relatively little range in the longer time period like the U.S. dollar after the collapse of the gold standard. It does not mean that the international monetary system will be stable but it will be less instable than nowadays.

Another proposal concerns an implementation of the single world currency as an extreme form of "dollarization" (Terzi, 2005). However, in my opinion, the above mentioned contradictory interests inside the global collective hegemony make such a solution impossible in the foreseeable future. A common North Atlantic currency between North America and euro zone seems to be more possible because of a lack of big political conflicts connected with similar political systems. However, economic crisis and recessions in the U.S.A. and in many European countries, especially in euro area, (e.g., in Greece, Spain, Portugal, Ireland and Italy) but also outside this zone (e.g., in Hungary and Island), make this solution impossible in the near future. 
Another important occurrence caused by the last two global recessions is breaking off the globalization processes in support of growing importance of regional problems in North America and Europe. It is connected with above mentioned question of two-speed world (Schwab, 2012) that was known but ignored until the global recessions, especially in Europe. It was connected with a political pressure for the European Union enlargements in 2004 and 2007 (Staszczak, 2011). On the one way, the EU is the biggest single market and the most integrated organization over the world, but on the other hand, it is not any homogeneous structure because of various economic development of member states. There are high developed member countries like Germany, Britain, France, Belgium and Netherlands but there are also less developed states like Bulgaria and Romania. Therefore, there is a question about a possibility of equal development and integration of these countries. This problem was considered before the EU enlargements in 2004 and 2007 because of big differences in economic development and in political interests of old member states (Hughes, 1996). The problem to deep the European integration is more important during the global recessions which emphasizes enormous economic difficulties of some EU countries, for instance a big crisis in Greece and Spain which is dangerous for the EU unity and for euro currency. Less developed EU countries are not able to fulfill the requirements of the integration, for instance a limit of the budget deficit or common economic policy, etc. Therefore, the European integration of the one speed is only non realistic idea, while the integration of the two speeds, is the nearest to the reality.

The acknowledgement of euro, the U.S. dollar and yuan as "anchors" or so called multipolar "tripod" of reserve currencies (Schwab, 2012) by the global collective hegemony represented by World Economic Forum is a step into the global relative stability. However, there are problems of the world economic (including financial) crisis connected with a lack of enough control over speculative capital flows and banks credit policies (Staszczak, 2012). Questions of the enormous growth of international capital flows after their strong limitation within the framework of the Bretton Woods system have been discussed since many years (Reszat, 1999). This situation is better solved in China where international capital flows are strongly controlled (Staszczak, 2012; Xinhua, 2010). There were also some attempts to better control the banks activities forced by the global crisis and recessions in 2008-2009 and started in 2011. However, the enormous importance of the biggest transnational corporations including banks in the global collective hegemony shatters the opportunities of ideological Western states to their effective control (Staszczak, 2011 and 2012). In spite of the contradictory interests in the global collective hegemony, the world deep recessions force consensus inside the hegemony to reform and stabilize the international monetary system. This consensus can stabilize this system worse than the gold standard but better than it is nowadays.

Many countries in debts and with a relatively high inflation and high internal prices have relatively strong currencies, e.g., U.S. dollar, euro, British pound. It is connected with a believe of investors and speculators in a relative stability of some 
currencies, e.g., during political instabilities the U.S. dollar is deemed as a stable world currency in spite of its relative weakness in many periods mentioned above. If old banknotes are not retired from the circulation by authorities like in the U.S.A. the currency is popularly considered as strong. However, 20 dollar coin contained $1 \mathrm{oz}$ gold in the beginning of 1930s. Nowadays, the gold price is unstable but still high according to 1930s. 1 oz gold amounted about 1770 U.S. dollars in September 2012 and 1223,60 U.S. dollars on July 6, 2013 (Goldprice, 2013). It proves investments in gold in the first part of the crisis when many people have a surplus of money and a sale of gold later when many people feel economic difficulties. Moreover, this example shows a real weakness of the U.S. dollar in the long period.

All contemporary currencies are depreciated in the longer time period because of inflation. However some money are depreciated more rapidly and other currencies are depreciated slowly. Exchange rates not always reflect these real changes in currencies depreciations. This situation promotes instability and speculations. Needs to put more and more money to the economy during a crisis in the aim to increase demand that promotes a bigger production seems to be more important for the global collective hegemony than a perspective of more stable gold currencies.

\section{CONCLUSIONS}

This paper proves two hypotheses that the instability of currencies is connected with a lack the gold standard and with contradictory interests inside the global collective hegemony of state-powers and major transnational corporations. Looking from the historical perspective and according to the Kopernik's law, that instability is inescapable because of the bad, i.e., valueless money used over the world. There are no discussion within the global collective hegemony to return to the gold or other merchandise money in the aim to connect coins with a real value. Therefore, a stability of exchange rates is impossible in the long run. A different global demand (including a speculation) for particular currencies connected with their different supply into the circulation let define some currencies as strong and other as weak ones in the particular time periods according to changes of the exchange rates. The economic difficulties in the U.S.A. and EU, especially euro zone cause a growth of instability of the contemporary world currencies.

However, according to the state-corporation hegemonic stability theory, there is necessary to find a compromise inside the global collective hegemony for a relative stability of exchange rates basing on symbolically valuable currencies in the aim to stabilize the world monetary system and the global economy. Smaller and more foreseeable changes in exchange rates are favorable for a development of the international trade and the world economy. Therefore, there is necessary to add Chinese yuan to the triad of the most important world currencies together with the U.S. dollar and euro. A new international monetary system should also acknowledge other important currencies, including ones of some emerging economies.

Moreover, the global crisis and recessions in 2008-2009 and started in 2011 
proved the necessity of a better state control over capital flows and activities of transnational corporations, including banks. However, such a control is difficult or almost impossible in the ideological Western part of the global collective hegemony because corporations are important participants of this hegemony. The contradictory interests within the hegemony must conduct to repetitive instabilities of the world monetary system.

\section{REFERENCES}

Chu, D. L. (2009) “Seeking Alpha. Gold, Dollar, Euro: 2010 “Menage a Trios”?” — http://seekingalpha.com/article/179866-gold-dollar-euro-2010-menage-a-trois dated: December 27.

Coffey, Peter (1974) The World Monetary Crisis. London: Macmillan Press.

Cywinski, Henryk (1986) Z dziejow pieniadza na swiecie [History of the Money over the World]. Warszawa: Krajowa Agencja Wydawnicza RSW „Prasa-Ksiazka-Ruch”.

Cywinski, Henryk (1987) Dziesiec wiekow pieniadza polskiego [Ten Centuries of the Polish Money]. Warszawa: Ludowa Spoldzielnia Wydawnicza.

Dornbusch, Rudiger (1976) "Expectations and Exchange Rate Dynamics", Journal of Political Economy, 84: 1161-1176.

Dornbusch, Rudiger, Fischer, Stanley (1987) Macro-economics. Fourth edition. New York: McGraw-Hill Book Company.

Economic Report of the President (1996). Transmitted to the Congress together with the Annual Report of the Council of the Economic Advisers, U.S. Government Printing Office, Washington, DC February.

Economic Report of the President (2000). Transmitted to the Congress together with the Annual Report of the Council of the Economic Advisers, U.S. Government Printing Office, Washington, DC, February.

Economic Report of the President (2012). Transmitted to the Congress together with the Annual Report of the Council of the Economic Advisers, U.S. Government Printing Office, Washington, DC, February.

Eichengreen, Barry (2005) Sterling's Past, Dollar's Future: Historical Perspectives on Reserve Currency Competition. University of California, Berkeley http://emlab.berkeley.edu/ eichengr/research/tawney_lecture2apr29-05.pdf date: April.

Eurostat (2012). Statistical Office of the European Communities, Luxembourg, http://epp.eurostat. ec.europa.eu Last update April 4.

Friedman, Milton (1953) “The Case for Flexible Exchange Rates” [in] Friedman, Milton

Friedman, Milton (1953) Essays in Positive Economics. Chicago: University of Chicago Press.

Goldprice (2013) — http://goldprice.org date: July 6.

Hughes, K. (1996) “The 1996 Intergovernmental Conference and EU Enlargement”, International Affairs, 1 (Vol. 72): 1-8.

Ikenberry, G. John (ed.) (1988) Reason of the State. Oil Politics and the Capacities of American Government. Ithaca, London: Cornell University Press.

Johnson, Lynn K. (1991) America as a World Power. Foreign Policy in a Constitutional Framework. New York: McGraw-Hill.

Keynes, John M. (2007 [1936]) The General Theory of Employment, Interest and Money, Basingstoke: Palgrave Macmillan.

Kopernik, Mikolaj (Copernicus, Nicolas) (2001 [1926, 1543]) O obrotach cial niebieskich i inne pis$m a$ [On the Revolutions and Other Letters], (translation: L. A. Birkenmajer). Warszawa: De Agostini, Altaya. 
Kopernik, Mikolaj (2001 [1926, 1528]). "Sposob urzadzenia monety” [Method of the Coin Management], [in] Kopernik, Mikolaj

Krugman, Paul (2002) “Exchange Rates”, The Concise Encyclopedia of Economics - http://www. econlib.org/library/Enc1/ExchangeRates.html

McConnell, Campbell R. (1987) Economics. Principles, Problems, and Policies, Tenth edition. New York: McGraw-Hill Book Company.

McEachern, William A. (1988) Economics. A Contemporary Introduction. Cincinnati, Ohio: South-Western Publishing Co.

Oresme, Nicolas (1956 [1350s]) Treatise on Money [Treatise on the Origin, Nature, Law and Alterations of Money], (translation and introduction Ch. Johnson). London: Thomas Nelson and Sons Ltd.

Park, Y. C. (2011) “The Role of Macro-prudential Policy for Financial Stability in East Asia's Emerging Economies”, ADBI Working Paper Series [Asian Development Bank Institute], 284: 1-27.

Reszat, B. (1999) "Currency Trading and International Financial Stability", Intereconomics March/ April: 64-71.

Rothbard, Murray N. (2006) An Austrian Perspective on the History of Economic Thought, Vol. I: Economic Thought Before Adam Smith. Auburn: Ludwig von Mises Institute.

Samuelson, Paul A. \& Nordhaus, William D. (1985) Economics, Twelfth edition. New York: McGraw-Hill Book Company.

Schwab, Klaus (2012) „Euro, Dollar, Yuan Uncertainties. Scenarios on the Future of the International Monetary System”, World Scenario Series [World Economic Forum, Geneva, Switzerland], 1-34 - http://www.weforum.org/issues/strategic-foresight date: June

Staszczak, Dariusz E. (2002) "Global Political-economic Spiral as a Model of the World Changes", Studia Polityczne, 13: 329-352.

Staszczak, Dariusz E. (2004 [2001]) USA-UE. Wzajemne stosunki na tle zmian systemu swiatowego [U.S.A.-EU. Mutual Relations in a Background of the World System Changes]. Torun: Wydawnictwo Adam Marszalek.

Staszczak, Dariusz E. (2011) "Theoretical Interpretations of the European Union Enlargement: Perspectives from a New Global Paradigm”, Journal of Knowledge Globalization, 1, Vol. 4: 71-92.

Staszczak, Dariusz E. (2012) "International Trade and Capital Flows as the Sources of the Nations Poverty or Richness”, Conference Proceedings [Knowledge Globalization Conference, Boston, Massachusetts, October 16-17, 2011, Published Annually; Sawyer School of Business; Suffolk University, Boston, Massachusetts; Conference Papers: (C) Knowledge Globalization Institute, Boston, Massachusetts, USA ], 1, Vol. 5: 146-165.

Terzi, Andrea (2005) "International Financial Instability in a World of Currencies Hierarchy", Working Paper [Instituto di Economia e Finanza, Universita Cattolica del Sacro Cuore, Milano, Italy], 64: 1-22.

Xinhua, (2010) “China to Enhance Monitoring of Cross-border Capital Flows”, China Daily, http:// www.chinadaily.com.cn/business/2010-06/11/content_9964751.htm date: June 11.

Ying, F. (2011) "China and Europe Can Build a New Partnership out of This Crisis", The Guardian - http://www.guardian.co.uk/commentisfree/2011/dec/12/china-europe-partnership date: December 12 . 